\title{
Case Based Reasoning Diagnosis Hama dan Penyakit Tanaman Nilam
}

\author{
${ }^{1}$ Rabiah Adawiyah \\ ${ }^{1}$ Prodi Sistem Informasi, Fakultas Teknologi Informasi \\ ${ }^{1}$ Universitas Sembilanbelas November Kolaka \\ 1e-mail: adawiyah.heru@gmail.com
}

\begin{abstract}
Abstrak-Nilam merupakan tanaman penghasil minyak asiri yang dikenal dengan minyak nilam (patchouli oil) yang mempunyai nilai ekonomi tinggi dan prospek yang cerah. Tanaman nilam yang digunakan sebagai bahanbaku kosmetik, parfum, antiseptik, sabun, obat, dan insektisida. Tanaman nilam merupakan wahana agrobisnis bagi petani dan pengusaha dalam rangka peningkatan pendapatan dan kesejahteraan (taraf hidup) masyarakat tani, sekaligus penyedia bahanbaku secara kontinu bagi industri minyak nilam. Dalam pengembangan dan peningkatannya tanaman nilam mengalami beberapa kendala seperti serangan hama dan penyakit yang mengakibatkan rendahnya hasil panen pada tanaman nilam khususnya pada daerah Desa Gunung Sari Kecamatan Watubangga Kabupaten Kolaka. Hama dan penyakit merupakan salah satu penyebab rendahnya produksi daun nilam yang perlu selalu diantisipasi perkembangannya karena dapat menimbulkan kerugian bagi petani, sehingga perlu diantisipasi secara dini. Penanganan tanaman nilam yang terserang hama dan penyakit seringkali terhambat karena masih banyak petani yang awam dalam merawat tanaman nilam yang tidak tahu bagaimana cara menanganinya. Case Based Reasoning (CBR) merupakan salah satu metode yang mampu melakukan penalaran atau memecahkan permasalahan berdasarkan pengalaman kasus yang telah ada yang digunakan sebagai solusi masalah baru. Sistem yang dibangun dalam penelitian ini adalah sistem CBR untuk melakukan diagnosis penyakit Tanaman Nilam sehingga petani mendapatkan informasi tentang cara penanganan tanaman nilam dengan benar. Proses diagnosis yaitu memasukkan kasus baru dibandingkan dengan kasus lama lalu dihitung nilai similaritasnya menggunakan metode Nearest neighbord. Akurasi sistem yang dihasilkan dalam penelitian ini sebesar $80 \%$.
\end{abstract}

Kata Kunci-Case Based Reasoning, Nearest Neighbord, Tanaman Nilam.

Abstract-Patchouli is an oil-producing plant asiri known as patchouli oil (oil patchouli oil) which has a high economic value and a bright prospect. Patchouli plants used as cosmetic ingredients, perfumes, antiseptics, soaps, drugs, and insecticides. Patchouli plant is an agribusiness for farmers and entrepreneurs in order to increase the income and welfare (living standard) of the farm community, as well as provider of continuous materials for the patchouli oil industry. In the development and improvement of patchouli plants experience several obstacles such as pests and diseases that resulted in low yields on patchouli plants, especially in the village of Gunung Sari Watubangga District Kolaka. Pests and diseases are one of the causes of the low production of patchouli leaves that should always be anticipated because the development can cause losses for farmers, so it needs to be anticipated early. Handling patchouli plants are attacked by pests and diseases are often hampered because there are still many farmers who are lay in treating patchouli plants that do not know how to handle it. Case Based Reasoning (CBR) is one method that can reason or solve problems based on existing case experiences that are used as solutions to new problems. The system built in this research is the CBR system to make the diagnosis of Nilam Plant disease so that farmers get information about how to properly cultivate patchouli plants. The diagnostic process of inserting a new case compared to the old case then calculated its similarity value using the Nearest neighbord method. The accuracy of the system generated in this research is $80 \%$.

Keywords—Case Based Reasoning, Nearest Neighbord, Patchouli Plants. 
INTENSIF, Vol.2 No.1 February 2018

ISSN: 2580-409X (Print) / 2549-6824 (Online)

http://ojs.unpkediri.ac.id/index.php/intensif

\section{PENDAHULUAN}

Perkembangan teknologi yang sangat berkembang dan memegang peranan penting dalam berbagai hal, salah satunya adalah dalam bidang pertanian dan perkebunan, namun pada faktanya saat ini masih banyak instansi pemerintahan dalam bidang pertanian dan perkebunan yang belum memanfaatkan peran dari teknologi informasi dengan maksimal untuk hasil yang efisien dan efektif guna untuk membantu masyarakat atau petani dalam menyelesaikan masalah dalam bidang pertanian dan perkebunan, sehingga masih banyak ditemukan kekurangan, salah satunya adalah sulitnya petani untuk mendapatkan informasi tentang hama dan penyakit yang menyerang pada tanaman mereka khususnya pada tanaman nilam.

Nilam merupakan tanaman penghasil minyak asiri yang dikenal dengan minyak nilam (patchouli oil) yang mempunyai nilai ekonomi tinggi dan prospek yang cerah. Tanaman nilam yang digunakan sebagai bahan baku kosmetik, parfum, antiseptik, sabun, obat, dan insektisida. Sebagai penghasil minyak asiri, nilam menjadi komoditas ekspor yang mampu menghasilkan devisa bagi Negara. Tanaman nilam merupakan wahana agrobisnis bagi petani dan pengusaha dalam rangka peningkatan pendapatan dan kesejahteraan (taraf hidup) masyarakat tani, sekaligus penyedia bahan baku secara kontinu bagi industri minyak nilam [1].

Dalam pengembangan dan peningkatannya tanaman nilam mengalami beberapa kendala seperti serangan hama dan penyakit yang mengakibatkan rendahnya hasil panen pada tanaman nilam khususnya pada daerah Desa Gunung Sari Kecamatan Watubangga Kabupaten Kolaka. Didesa ini tanaman nilam dijadikan sebagai mata pencarian utama untuk memenuhi kebutuhan ekonomi karena harga minyak nilam yang mahal, sementara itu banyak petani tanaman nilam yang mengeluh karena hama dan penyakit pada tanaman mereka. Hama dan penyakit merupakan salah satu penyebab rendahnya produksi daun nilam yang perlu selalu diantisipasi perkembangannya karena dapat menimbulkan kerugian bagi petani, sehingga perlu diantisipasi secara dini [1]. Penanganan tanaman nilam yang terserang hama dan penyakit seringkali terhambat karena masih banyak petani yang awam dalam merawat tanaman nilam yang tidak tahu bagaimana cara menanganinya. Banyak petani yang telah bertanya tetangga ataupun sesama penanam tanaman nilam namun pertanyaan tersebut tidak terjawab, sedangkan untuk bertanya dengan pakarnya langsung sulit karena jarak rumah yang jauh. Hal tersebut memerlukan waktu yang relatif lebih lama bila dibandingkan dengan menggunakan sebuah sistem yang dapat berpikir seperti manusia (pakar) ke dalam komputer agar komputer dapat menyelesaikan masalah seperti layaknya seorang pakar. 
INTENSIF, Vol.2 No.1 February 2018 ISSN: 2580-409X (Print) / 2549-6824 (Online) http://ojs.unpkediri.ac.id/index.php/intensif

Sistem pakar merupakan sistem yang menggunakan fakta, pengetahuan, dan teknik penalaran dalam memecahkan masalah yang biasanya hanya dapat dipecahkan oleh seorang pakar dalam bidang tertentu [2]. Dalam hal ini sistem pakar diterapkan untuk mengidentifikasi dan memberikan solusi terhadap hama dan penyakit pada tanaman nilam. Sistem pakar ini menghasilkan keluaran berupa kemungkinan hama dan penyakit berdasarkan gejala yang terlihat pada tanaman nilam.

Sistem pakar yang digunakan dalam merancang sistem tersebut yaitu sistem pakar yang berbasis kasus biasa disebut dengan Case Based Reasoning (CBR). Pada umumnya penyelesaian masalah yang dihadapi dapat dilakukan dengan melihat pengalaman-pengalaman yang telah dimiliki, ataupun berdasarkan pengalaman dari orang lain. Hal inilah yang menjadi dasar sehingga menghasilkan suatu metode baru yang dikenal dengan penalaran berbasis kasus (case based reasoning). Representasi pengetahuan (knowledge representasi) dari sebuah basis kasus reasoning adalah berupa kumpulan kasus (case base) yang telah terjadi sebelumnya. Dalam penyelesaian suatu permasalahan CBR menggunakan solusi dari kasus terdahulu yang mirip dengan kasus saat ini. Proses mencari kedekatan antara masalah baru dengan kasus lama dapat menggunakan berbagai macam metode, dimana metode ini mempengaruhi keberhasilan dari kerja CBR dalam menentukan kasus lama yang paling mirip dengan masalah baru (target case). Salah satu metode yang digunakan dalam penelitian ini untuk menghitung kemiripan (similarity) adalah Nearest neighbor.

Penelitian yang menggunakan CBR untuk diagnosis penyakit sesuai dengan jurnal [3] untuk mengembangkan basis pengetahuan dalam sistem diagnosis penyakit. [4] Penyusunan indeks pada basis kasus didasarkan pada kelas dan subkelas penyakit THT dengan menggunakan jaringan syaraf tiruan model backpropagation, sedangkan pengukuran similarity menggunakan metode Nearest neighbor dengan cosine coefficient, [5] pengembangan sistem cerdas menggunakan penalaran berbasis kasus (CBR) untuk mendiagnosis penyakit akibat virus eksantema. Dalam penelitian ini jenis-jenis penyakit yang dihasilkan oleh virus eksantema diantaranya: cacar air, campak, valiora. Teknik retrieval yang digunakan adalah probabilitas bayes. Dengan menggunakan metode CBR yang memiliki keunggulan salah satunya yaitu mengurangi akuisisi pengetahuan dengan menghilangkan kebutuhan untuk ekstrak model atau kumpulan dari aturan-aturan, seperti yang diperlukan dalam model/sistem yang berbasis aturan. Akuisisi pengetahuan pada CBR terdapat pada kumpulan pengalaman/kasus-kasus sebelumnya dengan menggunakan similarity Nearest neighborn diharapkan dapat melakukan diagnosis penyakit tanaman nilam lebih cepat dan lebih baik. 
INTENSIF, Vol.2 No.1 February 2018

ISSN: 2580-409X (Print) / 2549-6824 (Online)

http://ojs.unpkediri.ac.id/index.php/intensif

\section{METODE PENELITIAN}

\subsection{Deskripsi Sistem}

Case Based Reasoning (CBR) adalah model penalaran yang menggabungkan pemecahan masalah, pemahaman dan pembelajaran. Perkerjaan tersebut dilakukan dengan berbagai macam situasi yang sudah disimpan didalam system yang disebut sebagai kasus dapat direpresentasikan sebagai suatu siklus proses yang dibagi menjadi empat sub proses [6]:

1. Retrieve merupakan proses menemukan kasus baru yang mirip dengan kasus lama yang tersimpan dicase base kemudian digunakan kembali untuk mendapatkan solusi dari kasus yang baru. Terdapat beberapa metode dalam retrieval pada CBR, diantaranya algoritme pohon keputusan dan algoritme nearest neighbor.

2. Reuse menggunakan kembali kasus-kasus yang ada dan dicoba untuk menyelesaikan suatu masalah sekarang. Karena sangat jarang ada kasus baru yang sama persis dengan kasus sebelumnya, maka solusi dari kasus sebelumnya perlu diubah agar sesuai dengan kasus yang baru.

3. Revise merubah dan mengadopsi solusi yang ditawarkan jika perlu. Terdapat dua tugas utama dari tahapan ini yaitu :

a. Evaluasi Solusi dapat dilakukan dengan mendapatkan tanggapan dari pakar.

b. Memperbaiki Kesalahan (adaptasi), proses untuk memperbaiki kesalahan Proses ini sebut dengan adaptasi. Beberapa metode adaptasi adalah:

a. Substitusion.

b. Transformation.

c. Reinstantiation merupakan proses mengkopi dan menggunakan solusi dari kasus lama untuk dijadikan solusi pada kasus baru.

4. Retain proses penyimpanan dan validasi solusi dari kasus baru kedalam case based. 
INTENSIF, Vol.2 No.1 February 2018

ISSN: 2580-409X (Print) / 2549-6824 (Online)

http://ojs.unpkediri.ac.id/index.php/intensif

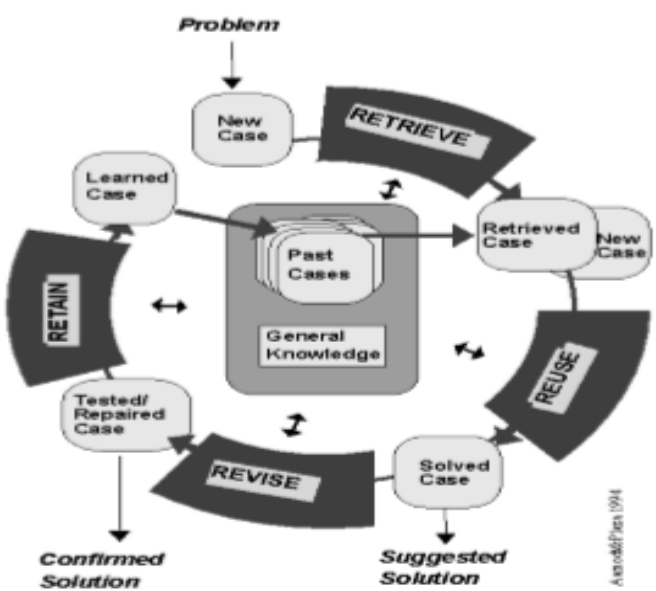

Gambar 1. SiKLus Metode CASE-BASED REASONING (AAMODT \& PlaZA, 1994)

Sistem CBR untuk diagnosis hama dan penyakit tanaman nilam dengan melakukan 2 proses yaitu proses pertama memasukkan data kedalam basis kasus yang diperoleh dari kantor Dinas Pertanian Kab.Kolaka. adapun nama hama dan penyakit yaitu Hama Ulat Penggulung Daun (Pachyzaneba stutalis) kode P1, Belalang (Orthoptera) Kode P2, Ulat Pemakan Daun (Grylidae) Kode P3, Kutu dompalan putih (pseudococcus sp.) kode P4, Layu Bakteri Kode P5, Buldok (Heprosep) Kode P6, Akar putih Kode P7. Kemudian proses kedua yaitu melakukan proses pengujian data dengan memasukkan data kasus baru, digunakan metode Nearest neighbor untuk menemukan kasus termirip sehingga diperoleh jenis hama dan penyakit serta solusinya berupa penanganan.

Proses retrieval digunakan untuk menemukan hasil diagnosis dan solusi pada target case dilakukan dengan memasukkan data gejala untuk dihitung nilai similaritasnya dengan kasus tersimpan dalam basis kasus. Setiap fitur memiliki bobot dengan nilai tertentu. Nilai bobot diperoleh dari pakar. Kesamaan masing-masing fitur dikalikan dengan bobot menggunakan rumus similarity lokal persamaan (1) simbolik, selanjutnya dihitung secara keseluruhan menggunakan rumus similarity global Nearest neighbor persamaan (2). Apabila nilai similarity tersebut lebih kecil dari nilai threshold yang telah ditentukan yaitu 0.6, maka solusi dari kasus tersebut harus direvisi terlebih dahulu oleh pakar dan disimpan ke basis kasus setelah proses revisi dilakukan. Dan jika hasil similarity diatas treshold maka dilakukanlah proses reuse yaitu sistem menghasilkan keluaran (output) berupa jenis hama dan penyakit yang paling mirip dengan masalah baru tersebut serta solusi berupa penangananya. Hasil perhitungan pada masing-masing 
INTENSIF, Vol.2 No.1 February 2018

ISSN: 2580-409X (Print) / 2549-6824 (Online)

http://ojs.unpkediri.ac.id/index.php/intensif

kasus diurutkan dari nilai tertinggi ke terendah. Nilai yang tertinggi adalah kasus yang paling mirip dengan masalah baru. Nilai kemiripan antara 0 sampai dengan 1. Jika nilai kemiripan $=1$, maka kasus tersebut samapersis sehingga tidak perlu disimpan dalam basis kasus karena kasus seperti itu sdh ada, dan sebaliknya semakin kecil nilai similaritasnya maka kasus tersebut semakin tidak mirip dan jika berada dibawah nilai treshold maka kasus tersebut harus mengalami proses revisi.

$$
\begin{aligned}
& f(s, t)=\left\{\begin{array}{cc}
1 & \text { jikas } s=t \\
0 & \text { lainnya }
\end{array} \text {, dimana } s, t \in\{\text { benar, salah }\}\right. \\
& \operatorname{sim}(S, T)=\left(\frac{\sum_{i=1}^{n} f\left(S_{i}, T_{i}\right) * w_{i}}{\sum_{i=1}^{n} w_{i}}\right)
\end{aligned}
$$

\subsection{Representasi Kasus}

Kasus direpresentasikan dalam bentuk frame berupa kumpulan fitur-fitur yang menjadi ciri kasus tersebut dan solusi untuk menangani kasus tersebut. Fitur-fitur tersebut bisa didapat dari akuisisi pengetahuan seperti melakukan wawancara dengan pakar, mengambil referensi dari buku-buku yang terkait masalah penelitian serta teknik pengumpulan data lainnya. Kumpulan kasus yang telah diperoleh dari Petani dan pakar pada kantor Dinas Pertanian Kab.Kolaka.. Representasi kasus dalam bentuk frame sesuai dengan gambar 2 .

\begin{tabular}{|l|l|}
\hline Nomor Kasus & $: 01$ \\
\hline Gejala & $:$ G1 (Batang Habis) \\
\hline & $:$ G2 ( Batang dan Cabang yang masih muda rusak) \\
\hline & $:$ G3 ( Daun berlubang ) \\
\hline & $:$ G4 ( Daun Terlihat Transfarant) \\
\hline & $:$ G5 ( menyerang dari tepi daun lalu ketengah ) \\
\hline Hasil Diganosis & $:$ P2 (Belalang (orthoptera) \\
\hline Solusi & $:$ \\
\hline
\end{tabular}

Gambar 2. REPRESENTASI BASIS KASUS DALAM BENTUK FRAME 
INTENSIF, Vol.2 No.1 February 2018

ISSN: 2580-409X (Print) / 2549-6824 (Online)

http://ojs.unpkediri.ac.id/index.php/intensif

2.3 Proses Retrieval untuk Diagnosis Hama dan Penyakit Tanaman Nilam

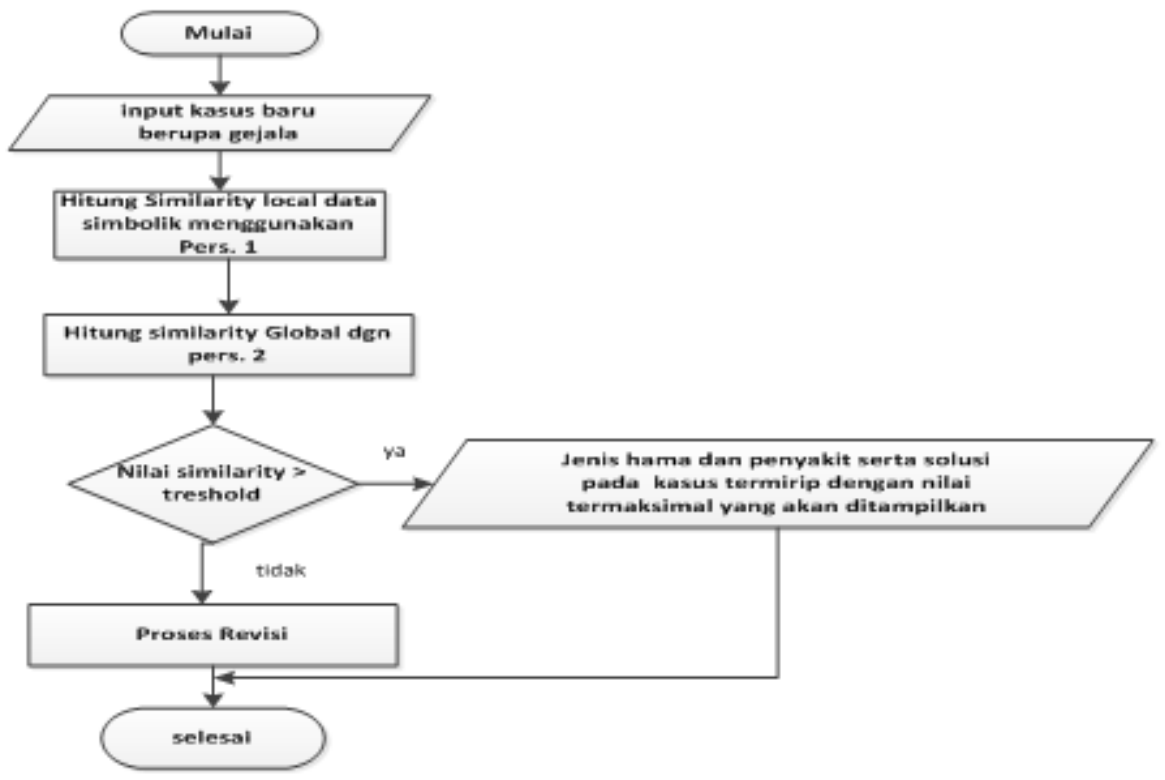

Gambar 3. FLOWCHART CBR UNTUK DIAGNOSIS HAMA DAN PENYAKIT TANAMAN NILAM

Proses retrieval user bertindak sebagai pemakai memasukkan data target case atau masalah baru dengan memasukkan data gejala yang dialami tanaman nilam. Kemudian dilakukan proses similarity menggunakan Nearest Neighbor untuk menemukan kasus termirip dengan solusi berupa cara penanganannya sesuai pada Gambar 3.

Berikut ini contoh kasus proses perhitungan similarity menggunakan Nearest Neighbord dengan mengambil 2 contoh kasus pada basis kasus sesuai dengan Gambar 4. Pada Gambar 4 menunjukkan basis kasus dari sistem CBR yang terdiri dari 20 kasus dan mempunyai gejala dari masing - masing kasus berbeda - beda sesuai dengan data sebenarnya dan dilengkapi dengan jenis hama dan penyakitnya. Basis kasus inilah yang menjadi dasar proses similarity atau pencocokan kasus antara kasus lama dengan kasus baru sehingga pada kasus baru dapat ditemukan solusi dari kasus termirip. Pada basis kasus terdapat 2 penyakit P1, penyakit P2 mempunyai 3 kasus, Penyakit P3 $=2$ Kasus, Penyakit P4 $=2$ Kasus, Penyakit P5 $=3$ Kasus, Penyakit P6 $=6$ kasus sedangkan P7 $=2$ Kasus. 
INTENSIF, Vol.2 No.1 February 2018

ISSN: 2580-409X (Print) / 2549-6824 (Online)

http://ojs.unpkediri.ac.id/index.php/intensif

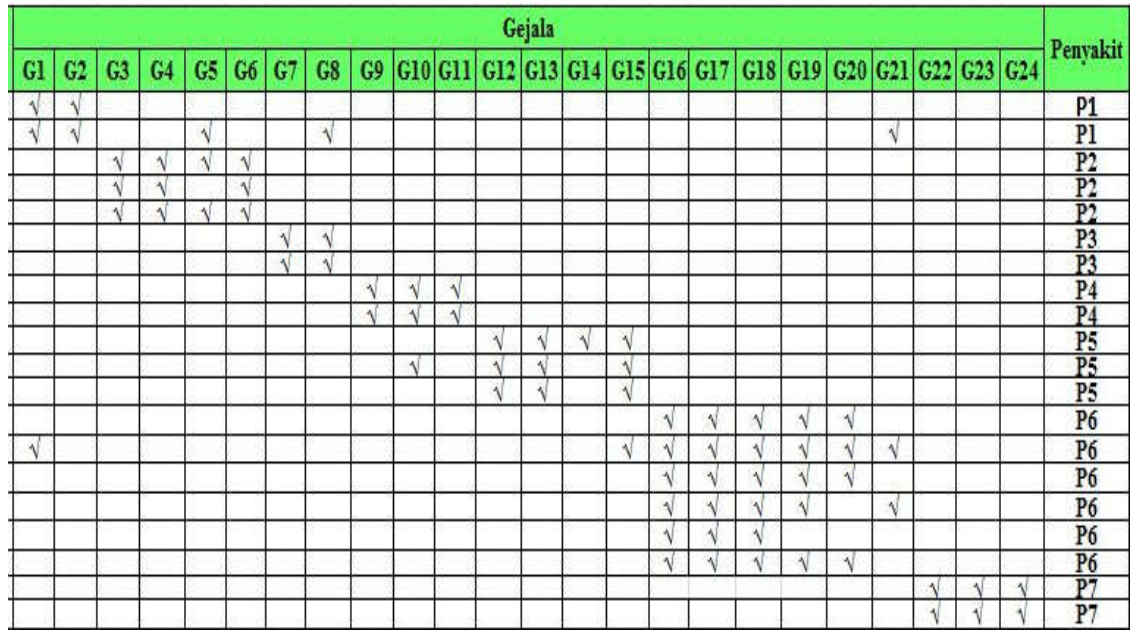

Gambar 4. BASIS KASUS

Tabel 1. CONTOH KASUS PROSES SIMILARITAS

\begin{tabular}{ccccccc}
\hline \multirow{2}{*}{ Data kasus } & \multicolumn{3}{c}{ Source case (S) } & \multicolumn{2}{c}{ Target case (T) } \\
\cline { 2 - 7 } & \multicolumn{2}{c}{ K03 } & \multicolumn{2}{c}{ K02 } & \multicolumn{2}{c}{ Kasus Baru } \\
\cline { 2 - 7 } & Gejala & Bobot & Gejala & Bobot & Gejala & Bobot \\
\hline Gejala & G3 & 10 & G1 & 10 & G3 & 10 \\
\hline Gejala & G4 & 8 & G2 & 8 & G4 & 8 \\
\hline Gejala & G5 & 7 & G5 & 7 & G5 & 7 \\
\hline Gejala & G6 & 6 & G8 & 6 & G6 & 6 \\
\hline Gejala & & & G21 & 10 & G7 & 10 \\
\hline $\begin{array}{c}\text { Diagnosis hama } \\
\text { dan penyakit }\end{array}$ & P2 & & P1 & & $\ldots \ldots . . . .$. & \\
\hline
\end{tabular}

Berikut proses perhitungan similaritas untuk kasus baru (target case) dengan kasus yang ada dalam basis kasus (source case) sesuai dengan Tabel 1.

1. Similaritas target case dengan source case (K03)

Similaritas Lokal :

Kedekatan fitur gejala, G3, G4, G5 dan G6 = 1 karena gejala tersebut sama berada pada target case dan source case, sedangkan G7 $=0$ karena hanya ada ditarget case dan tidak ada disource case begitupun sebaliknya.

Similaritas Global

$$
\operatorname{Sim}(S, T)=\frac{(1 * 10)+(1 * 9)+(1 * 7)+(1 * 6)+(0 * 10)}{10+9+7+6+10}=\frac{31}{41}
$$

$\operatorname{Sim}(S, T)=0,75$ atan $75 \%$ 
INTENSIF, Vol.2 No.1 February 2018

ISSN: 2580-409X (Print) / 2549-6824 (Online)

http://ojs.unpkediri.ac.id/index.php/intensif

2. Similaritas target case dengan source case (K02)

Similaritas Lokal :

Kedekatan fitur gejala G5 = 1 karena gejala pada target case tersebut sama juga berada source case, sedangkan untuk G3, G4, G6 dan G7 = 0 karena gejala pada source case tidak ada dalam target case begitupun sebaliknya.

Similaritas Global

$$
\begin{gathered}
\operatorname{Sim}(S, T)=\frac{(0 * 10)+(0 * 8)+(1 * 7)+(0 * 6)+(0 * 10)}{10+8+7+6+10}=\frac{7}{41} \\
\operatorname{Sim}(S, T)=0,17 \text { atau } 17 \%
\end{gathered}
$$

Berdasarkan perhitungan similaritas target case terhadap source case (K02 dan K03) dengan hasil K02 adalah $17 \%$ dan K03 adalah $75 \%$ maka nilai similaritas pada K03 lebih besar dibandingkan nilai similaritas K02, dapat disimpulkan bahwa source case (K03) merupakan kasus yang paling mirip dengan target case sehingga hama dan penyakit pada K03 yaitu P2 (Belalang (Orthoptera) juga menjadi solusi atau hasil diagnosis untuk target case.

\section{BAB III. HASIL DAN PEMBAHASAN}

\subsection{Pengujian Sistem}

Data uji kasus adalah sebanyak 10 kasus dan data basis kasus sebanyak 20 sesuai pada tabel 1. Pengujian dilakukan dengan memasukkan data uji satu persatu dan hasil diagnosis sistem dari data uji dikatakan benar jika memiliki hasil yang mirip dengan hasil diagnosis dari pakar dan memiliki hasil similaritas $>$ threshold.

Pengujian dilakukan menggunakan metode nearest neigbord sebagai proses similarity untuk memperoleh kasus yang termirip. Proses pengujian ini dilakukan untuk menguji tingkat kebenaran sistem dalam mendiagnosis hama dan penyakit tanaman nilam. Hasil pengujian menunjukkan bahwa terdapat 8 kasus yang terdiagnosis benar dan terdapat 2 data uji yang berada dibawah nilai < treshold yang artinya bahwa hasil diagnosis oleh sistem berbeda dengan data riil (diagnosis dari pakar) yaitu terletak pada data uji ke 4 dengan nilai similarity 0.43 dan data uji ke 10 dengan nilai similarity 0.55 .

INTENSIF: Jurnal Ilmiah Penelitian dan Penerapan Teknologi Sistem Informasi 
INTENSIF, Vol.2 No.1 February 2018

ISSN: 2580-409X (Print) / 2549-6824 (Online)

http://ojs.unpkediri.ac.id/index.php/intensif

\begin{tabular}{c|l|l|l|l|l|c|c|c|c|}
\hline no.kasus & \multicolumn{4}{|c|}{ Gejala } & nilai similarity & Hasil Diagnosa Sistem & Data Riil \\
\hline 1 & G1 & G2 & G15 & G16 & G17 & 0.80 & P6 & P6 \\
\hline 2 & G3 & G4 & G5 & G6 & G7 & 0.75 & P2 & P2 \\
\hline 3 & G15 & G16 & G17 & G18 & G19 & 1 & P6 & P6 \\
\hline 4 & G6 & G7 & G8 & G9 & G10 & 0.43 & P4 & P2 \\
\hline 5 & G3 & G4 & G5 & G6 & G7 & 0.75 & P2 & P2 \\
\hline 6 & G12 & G13 & G14 & G15 & G16 & 0.75 & P5 & P5 \\
\hline 7 & G20 & G21 & G22 & G23 & G24 & 0.67 & P7 & P7 \\
\hline 8 & G16 & G17 & G18 & G19 & G20 & 1 & P6 & P6 \\
\hline 9 & G15 & G16 & G17 & G18 & G23 & 0.86 & P6 & P6 \\
\hline 10 & G1 & G9 & G10 & G11 & G12 & 0.55 & P4 & P5 \\
\hline
\end{tabular}

Gambar 5. HASIL PENGUJIAN SISTEM

Pada Gambar 5 dapat dilihat bahwa hasil pengujian menunjukkan ada 2 data uji yang tidak sesuai yaitu terletak pada kasus 4 dan kasus 10 dengan menghasilkan nilai similarity dibawah nilai treshold.

\subsection{Evaluasi Sistem}

Evaluasi hasil pengujian sistem dilakukan dengan menghitung nilai akurasi sistem. Evaluasi dilakukan untuk mengetahui apakah hasil sistem yang telah dibangun layak untuk diterapkan dengan melihat hasil akurasinya.

$$
\begin{gathered}
\text { Akurasi Sistem }=\frac{\text { jumlah data uji benar }}{\text { jumlah data uji }}=\frac{8}{10} \\
\text { akurasi sistem }=0,8 \text { atau } 80 \%
\end{gathered}
$$

Hasil pengujian sistem dilakukan dengan menghitung nilai akurasi sistem dengan nilai yang diperoleh yaitu $=80 \%$ sehingga dapat dikatakan bahwa sistem CBR yang dibangun dapat mendiagnosis penyakit tanaman nilam dengan baik dan benar.

\subsection{Tampilan Interface}

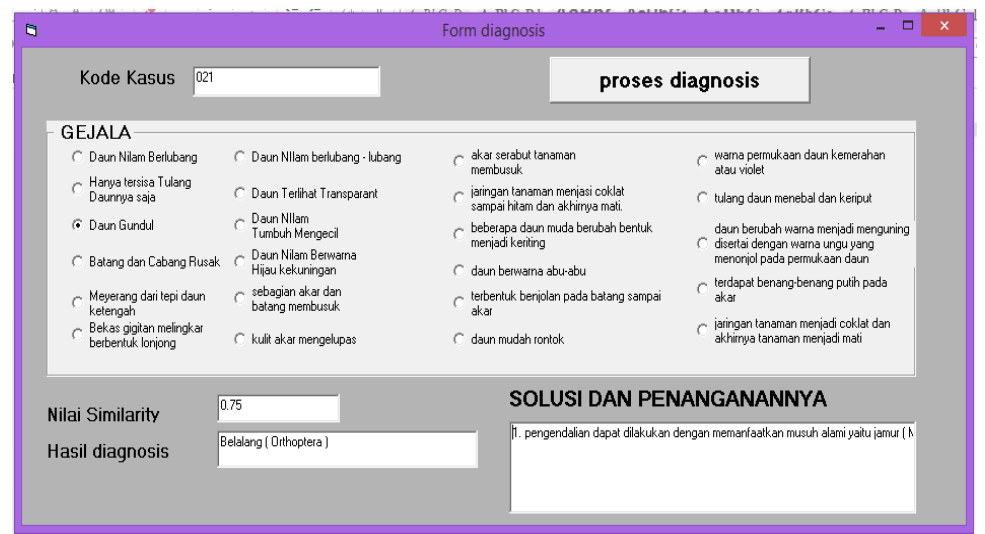

Gambar 6. TAMPILAN INTERFACE PROGRAM CBR UNTUK DIAGNOSIS HAMA DAN PENYAKIT 
INTENSIF, Vol.2 No.1 February 2018

ISSN: 2580-409X (Print) / 2549-6824 (Online)

http://ojs.unpkediri.ac.id/index.php/intensif

TANAMAN NILAM

Pada Gambar 6 menunjukkan bahwa form diagnosa merupakan form untuk menampilkan data hasil diagnosisnya serta solusi penangannanya. Form ini awalnya diinputkan kode kasus baru dan data gejala maka sistem akan menampilkan sebuah nilai similarity, hasil diagnosis sistem serta solusi penangannya yang akan memberikan masukan dan informasi kepada petani tentang jenis Hama dan Penyakit apa yang menyerang tanaman nilam serta bagaimana cara penanganannya.

\section{BAB. 4 KESIMPULAN DAN SARAN}

Sesuai dengan contoh kasus yang telah dilakukan terhadap 2 data kasus pada basis kasus, menunjukkan bahwa system CBR yang dibangun menggunakan metode nearest neighbor mampu menghasilkan diagnosis hama dan penyakit tanaman nilam tersebut nilai similarity terbesar terdapat pada kasus K03 dengan nilai 0.75 . Berdasarkan hasil pengujian yang diperoleh sesuai pada tabel 3 maka dapat dikatakan bahwa sistem CBR yang dibangun dapat mendiagnosis hama dan penyakit tanaman nilam dengan baik dan benar dengan hasil akurasi sistem yang diperoleh yaitu $80 \%$. adapun saran pada penelitian selanjutnya dapat ditambah teknik Indexing pada proses retrievalnya untuk lebih mempercepat proses retrievalnya. Pada penelitian selanjutnya, sistem dapat dibangun dalam bentuk website atau aplikasi mobile sehingga pengguna dapat lebih leluasa mengakses sistem kapan saja dan dimana saja. Metode retrieval menggunakan rumus sismilarity yang berbeda dapat digunakan pada penelitian selanjutnya agar dapat menambah pengetahuan bagi peneliti lainnya.

\section{DAFTAR PUSTAKA}

[1] Supriadi, Nilam (Pogostemon Cablin Benth). Bogor: Argo Inovasi, 2011.

[2] Hartati Dan Iswanti, Sistem Pakar Dan Pengembangannya. Yogyakarta: Graha Ilmu, 2008.

[3] Kusrini Dan Hartati, "Penggunaan Penalaran Berbasis Pengetahuan Dalam Sistem Diagnosis Penyakit," Pp. 1-7.

[4] Tedy Rismawan Dan Sri Hartati, "Case-Based Reasoning Untuk Diagnosa Penyakit Tht (Telinga Hidung Dan Tenggorokan)," Ijccs-Indonesian J. Comput. ..., Vol. 6, No. Sistem Pakar, Pp. 67-78, 2013.

[5] Agus Sasmito Dan Aribowo, "Pengembangan Sistem Cerdas Menggunakan Penalaran Berbasis Kasus ( Case Based Reasoning ) Untuk Diagnosa Penyakit Akibat Virus Eksantema," Telematika, Vol. 7, No. 1, Pp. 11-12, 2010.

[6] J. L. Kolodner, Case-Based Reasoning. 2006. 